Alpysbes, M.A. (2021). On the new accents in rethinking the history of the Golden Horde (in the understanding of the unity of the Turkic community). Rethinking of history: conflict of facts and hypotheses. Collection of Scientific Articles. European Scientific e-Journal, 7 (13), 102-135. Hlučín: "Anisiia Tomanek" OSVČ. (in Russian)

Алпысбес, М.А. (2021). О новых акцентах в переосмыслении золотоордынской истории (в понимании единства тюркского сообщества). Retbinking of history: conflict of facts and hypotheses. Collection of Scientific Articles. European Scientific e-Journal, 7 (13), 102-135. Hlučín: "Anisiia Tomanek" OSVČ.

DOI: $10.47451 /$ his2021-09-003

EOI: $10.11244 /$ his2021-09-003

The paper is published in Crossref, Internet Archive, Google Scholar, Academic Resource Index ResearchBib, JGate, ISI, CiteFactor, ICI, eLibrary databases.

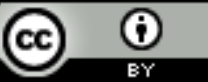

Makhsat A. Alpysbes

Doctor of History Science

Department of Kazakhstan History

L.N Gumilyov Eurasian National University

Nur-Sultan, Kazakhstan

E-mail: alpysbes@gmail.com

\title{
On the new accents in rethinking the history of the Golden Horde (in the understanding of the unity of the Turkic community)
}

\section{Abstract:}

The article's author undertakes the rethinking of certain interesting facts of the history of Ulug Ulus - the Golden Horde, through the scientific interpretation of the works of Abai, Shakarim, Mashhur Zhusup, and is aimed at analyzing views on the history of Ulug Ulus in the context of the unity of the Turkic peoples. This kind of discussion provides us with an opportunity to present a new vision of this issue, as well as to identify the necessary new accents to the consideration and presentation of the history of the Golden Horde state, to assess its role in the history of the Great Steppe. Research on the history of Ulug Ulus is now in demand by a wide readership and is very relevant. To date, there are many monographic studies, collections of materials, anthologies, scientific articles on the history of the Golden Horde that are popular and well-known among experts. There were publications, articles and books that consider particular and specific issues of the history of the Golden Horde. These works are for the most part works of generalizing nature, contributing to the assimilation of the given material, and their conclusions, comprehension, presentation and explanation of historical facts and events in the history of this state were carried out within the framework of the Soviet historical school. In teaching history, Golden Horde history is most often presented only as a period or stage of history, while in Soviet publications it was most often presented as the process of enslavement of peoples, as a one-sided interpretation, and there was an established name "Tatar-Mongol invasion", "Tatar-Mongol yoke". Nowadays such new concepts as "Turkic-Tatar states", "Turkic state" are sometimes used. Of course, in the conditions of hanging such labels, there could be no question of any objective view of the history of Ulug Ulus. We need the new view of the history of the Turkic peoples, free from prejudices, labels and clichés. As we see it, it is necessary to make a transition from the views and judgments that have developed within the framework of external sources and external historiography to the priority of internal sources and internal historiography. We propose to implement the experience of this kind 
of new vision by referring to the historical memory of the carriers and subjects of this history - the Turkic Kazakhs and other Turkic ethnic groups. So, for example, if you delve into the works of pre-revolutionary Kazakh authors, Abai, Shakarim, Mashhur-Zhusup, which were written before the establishment of the dominance of the Soviet paradigm in history, Chingiz Kagan appears to us not as an oppressor, but as a collector of the heritage and lands of the Turkic kagans.

\section{Keywords:}

Desht-i Kypchak, Ulug Ulus, Jochi, Batu, Uzbek, Urus-khan, Toktamys, Edige, Mongol-Tatars, Turkic peoples, culture, empire, post-Horde states.

Махсат A. Алпысбес Аоктор исторических наук профессор кафелры кафедра истории Казахстана Евразийский национальный университет имени $\Lambda . Н$. Гумилева Нур-Султан, Казахстан E-mail: alpysbes@gmail.com

\section{О новых акцентах в переосмыслении золотоордынской истории (в понимании единства тюркского сообщества)}

\section{Аннотачия:}

В статье предпринято переосмысление отдельных интересных фактов истории У ууг УАуса - Золотой Орды, посредством научной интерпретации трудов Абая, Шакарима, Машхур Жусупа, и анализ взглядов на вопросы истории Уиуг Улуса в контексте единства тюркских народов. Такого рода обсуждение представляет нам возможность Аля изложения нового видения данного вопроса, а также Аля выявление необходимых новых акцентов к рассмотрению и изложению истории золотоордынского государства, оценки его роли в истории Великой степи. Исследования по истории УАуг УАуса востребованы сейчас широкой читательской аудиторией и явцяются очень актуальным. К настоящему моменту существует много популярных в кругу специалистов монографических исследований, сборников материалов, хрестоматий, научных статей по истории Золотой Орды. Были публикации, статьи и книги, которые рассматривают отдельно взятые конкретные вопросы истории Золотой Орды. Эти работы по большей части явцяются трудами обобщающего характера, способствующего усвоению изложенного материала, а представленные выводы, осмысление, изможение и объяснение исторических фактов и событий истории Аанного государства были осуществлены в рамках шаблонов советской исторической школы. В преподавании истории золотоордынская история, чаще всего, представАяется Аишь как период или этап истории, а в советских изданиях оно, чаще всего, преАстав яяось как процесс порабощения народов, как однобокая трактовка, и бытовало утвердившееся наименования «татаро-монгольское нашествие», «татаро-монгольское иго». Теперь же порой используются такие новые понятия как «тюрко-татарские государства», «тюркское государство». Конечно, в условиях навешивания подобных ярлыков, речи о каком-либо объективном взгляде на историю Уяуг УАуса быть не могло. Нужен новый, трезвый и свободный от предрассудков, ярлыков, штампов и клише взгляА на историю тюркских 
народов. Как нам видится, нужно осуществить переход от взгАядов и суждений, сложившихся в рамках внешних источников и внешних историографий на приоритет внутренних источников и внутренней историографии. Опыт такого рода нового видения мы преАлагаем осуществить посредством обращения к исторической памяти самих носителей и субъектов этой истории - тюрков-казахов и Аругих тюркских этносов. Так, например, если вникнуть в труды дореволюционных казахских авторов, которые писали до установления господства советской парадигмы в истории, Абая, Шакарима, МашхурЖусупа, то Чингиз каган предстает нам не в роли угнетателя, а в роли собирателя наследия и земель тюркских каганов.

Клточевые слова:

Аешт-и Кыпчак, УАуг УАус, Ажучи, Бату, Узбек, Урус-хан, Токтамыс, ЕАиге, монголотатары, тюрки, культура, империя, пост-ордынские государства.

\section{Введение}

История - это, прежде всего, свидетельство об основах исторического становления государственности, воссоздающая историческую целостность общества и опредемяющая направление его развития. История на примере прошлого выявцяет преимущества развития общества или его недостатки, которые препятствова^и его развитию. История Ааёт примеры деятельности исторических персон, рассказывает о традиции преемственности государства. Поэтому, изучение золотоордынской истории важно Аһя многих тюркских народов и государств современности, так как многие из них сопричастны с ней исторически, и культурно-генетически. Новые акценты в его изучении будут связаны с тем, что УАуг УАус будет рассматриваться не отчужАенным взглядом, а тесно связанным и сугубо преемственным восприятием.

В истории ХХ века советская идеология, нацелившаяся на уничтожение этнической идентичности, чтобы созАать новое советское сообщество, не желала в своё время допускать осмысления и популяризации национальной истории народов, невольно вошедших в состав советского государства. Ясно, что национальная история как память взывает народ к изучению собственных культурных истоков и традиций, чтобы продолжить их и обогатить. История сохраняет этнос от поглощения совершенно Аругим, чужАым культурным массивом. Поэтому отнюдь не случайно, что национально-освободительное Авижение казахского народа в начале ХХ века называцось движение Алаш, ибо А^аш - это символическое имя первопредков, заложивших основы ранней тюркской государственности, и развивших их в послеАующем, олицетворяет собой образ каганов-единителей и собирателей земель. 
Авижение Алаш была призвана к воссозданию независимой казахской нации, независимой государственности казахского народа, которая оказацась в период становления мировой системы колониализма, вначале в вассальном положении в отношениях с Российской империей, а затем была полностью аннексирована и превратилась в ее колонию. ОАнако Россия, ранняя история которой начинается со зцополучного Московского государства, некогда сама была вассальным владением У ууг У ууса - Золотой Орды, в числе Аругих, таких же удельных княжеств. А название Алаш непосредственно связано с исторической мичностью Чингиз кагана, фигурирующий в исторической памяти казахского народа в качестве Алаша хана. Ибо мегенда исторической генеалогии казахского народа прямо восходит к фигуре мегендарного А^аша хана, к эпонимам Могоц, Татар, Ногай, Узбек, Шейбан, Абулхаир. согласно «Шежире тюрков» - «Тюркской истории» Абульгази. Вознамеренный создать российскую империю царизм, был заинтересован затушевать имя тюркской славы, представить интерпретацию ее истории в выгодном Аля себя свете.

Существует, собственно, восточная, западная историография освещения истории этого государства. Восточная историография характеризуется также как арабо-персидская, тюркская, тимуридская, шейбанидская, мусульманская, а западная представлена исследованиями европейской синологии, тюркологии и монголистики. В исследованиях истории Золотой ОрАы были преАставлены много разных материалов по вопросу изучения данной проблемы как художественных, научно-популярных, так и сугубо научно-исследовательских. На протяжений трех столетий существовавшей под исконным названием УАуг УАус (Великая держава).

Российская и советская историческая школа характеризуется вкладом таких учёных-классиков, как В.Г. Тизенгаузен (1825-1902 гг.), С.А. Козин (18791956 гг.), Б.Я. ВАаАимирцов (1884-1931 гг.), Б.А. Греков (1882-1953 гг.), А.Ю. Якубовский (1886-1953 гг.), М.Г. Сафаргалиев (1906-1970гг.), Г.А. ФедоровАавыдов (1931-2000 гг.), Т.М. Султанов $(1940$ г.). Они являются представителями разных научно-исторических направлений, например, В.Г. Тизенгаузен - историк-востоковеА, нумизмат, археолог, а Б.А. Греков специалист по истории Киевской Руси. Они являются представителями еАиной школы российской ориенталистики. А.Ю. Якубовский - выпускник Восточного факультета, ученик В.В. Бартольда, И.Ю. Крачковского, А.А. Рамаскевича (1885-1942). Г.А. ФёАоров-Аавыдов - искусствовеА, археолог, нумизмат А.А. Ромаскевич яв ялся учеником ираниста В.А. Жуковского. Б.Я. ВАаАимирцов - лингвист, языковеА, монголовеА. Труды этих исследователей 
Золотой ОрАы вошли в круг классических исследований востоковедения (Кумеков и Султанов, 1974).

ОАним из замечательных изданий по истории Золотой Орды стала акалемическая коллективная монография «Золотая ОрАа в мировой истории», в котором были представлены новейшие исследований ведущих учёных (Абзалов и Ар., 2016). В Аанном издании собраны основные новейшие исследования ведущих научных центров России и зарубежья. В предисловии Аанного издания ученый Р. Хакимов отмечает, что «изучение Укуса Ажучи (Золотой Орды) началось относительно недавно, в 1990-е годы, когда были сняты идеологические установки государства». Снятие запретов на свободное и полное изучение истории тюркских народов, само по себе означает необходимость переосмысления причин такого рода табу. И они были ведь связаны с желанием переставить ключевые акценты в понимании тюркской истории, переключить, условно говоря, полюса с плюса на минус, и наоборот, что Аолжно было служить, вероятно, Аля подмены представлений о прошлом, запутывание даже в вполне очевидных вещах.

В процессе переосмысления истории с точки зрения его сути и содержания, необходимо найти такие способы, которые бы избавили от заблужАений или фальшивых преАставлений, созданные односторонней оценкой советской исторической школы и его научной методологии. Если мы ищем способ преАставить еАиную и взаимосвязанную историю, то она Аолжна исходить из естественной основы, яАром которой может быть только коц ективная историческая память самого субъекта истории, а её собственные исторические и Ауховные источники должны быть ее первоосновой.

Был предпринят анализ произведений восточных авторов, прочтение источников нумизматики, манускриптов, разбор разАичных географических описаний или правовых актов - ярлыков ханов, родовых тамг, гербовых символик, генологических Аанных, цетописных хроник, записи послов, научно-монографических исследований, исторических романов, в которых, в соответствии их жанру, изцагаются факты его появления, развития, трансформации и угасания; рассказываются о фигуре Чингиз кагана, как основателе империи, его происхождении, недругах, союзниках, подвижниках, наследниках, завоеваниях, войске, характере государственного строительства, политических традициях, правовых установлениях.

В науке известны труды Б.Я. ВАадимирцова «Общественный строй монголов. Монгольский кочевой феодализм» (1934г.), М.Г. Сафаргалиева «РаспаА Золотой Орды», Б.А. Греков, А.Ю. Якубовский «Золотая ОрАа и её 
падение», Г.А. Фёдоров-Аавыдов «Общественный строй Золотой Орды». Все эти примеры специализации, круга интересов и научных компетенции показывают, что в фундаментальном изучении истории Укуг У ууса Аействительно были необходимы самые разные энциклопедические знания; вклаА нумизматов, археологов, востоковедов - тюркологов, монголоведов, арабистов, иранистов, этнографов, медиевистов, Аингвистов, языковедов.

В основу источниковой базы в золотоордынских исследованиях были положены широко известные сборники материалов по истории УАуг УАуса, вкАючающие труды и сочинения тюркских, китайских, арабских, персидских, монгольских авторов, Аневники и воспоминания представителей европейских миссий, а также письменные памятники грузинских, армянских и русских метописцев, и конечно же, ярлыки ханов и материалы их нумизматики, мемуарные работы Марко Поло, Уильям де Рубрука.

Классические исследователи истории Золотой Орды, как правило имели привычку изучать мишь отдельные аспекты, они чаще рассматривали конкретные вопросы, например политической истории, военной организации, этнический состав населения, историю монет или конкретного города, или правителя, но реже всего это оформлялась в целостную историю, именно как история отдельного государства. Но, собственно, само это государство как бы оставацось в тени того навязанного и условного ярцыка, или обозначения «империя». ОАнако империя это всего Аишь собственно результат государства и его политической машины управления.

История У Ауг УАуса является важным этапом формирования государств нового времени, поА возАействием которого они, собственно, и появились на политической арене, и на этнической карте мира многие государства, в период пост-позАнесредневековой истории человечества в новом формате. Причем это относится не только собственно к Казахстану, а именно ко многим государствам мира. Об этом писали многие историки, например в статье ученого А.Ш. Кадырбаева «Золотая Орда как предтеча Российской империи», и Аругие научные статьи рассматривают и изучают этот вопрос (Кадырбаев и Сыздыкова, 2017). Исследователь Ж.М. Сабитов в статье «Золотая Орда «падчерица» казахстанской историографии» также затронул вопросы об историческом правопреемстве Золотой Орды, справеАливо утвержАая, что У Аус Ажучи является «общим предком» как Аця казахов, так и многих тюркских народов (Сабитов, 2015).

Несмотря на то, что собран огромный массив материалов, научных, Аанных, и источниковых материалов, сложилась научная историография 
вопроса, не хватает кардинацьной смены взгляда, которая позволила бы правдиво интерпретировать видение истории УАуг УАуса в целом и сказать

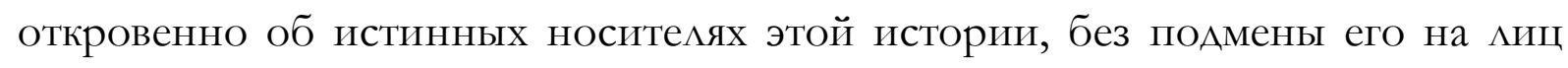
Аругих народов. ФонА этих Аанных, источников, научных комментариев, исследовательских текстов, сборники трудов и Аокументов хотя и преАставляют большой объём сведений, а новые изыскания значительно расширяют наше представление, в конечном итоге, требуется некий

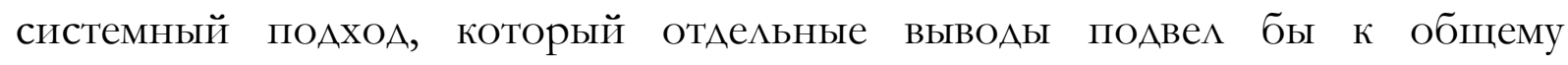
конкретному заключению. В переосмыслении золотоордынской истории, в первую очередь, следует исходить из обозначения основных акторов самого исторического процесса, связанных с этим государством - тюркскую конфедерацию тюркских племён, его основные составные части.

Следовательно, исторический взгляА «со стороны» Аолжен смениться на взгляА «на самих себя» или «изнутри», то есть пора прекратить смотреть на историю тюрков УАуг УАуса, на их правящие Аинастии, как основного источника института государственности этого образования глазами сторонних историографий, и сообщений сторонних внешних источников. Необходимо воспринять эту история как историю наших предков, наших тюркских прародителей. Значит, не следует быть в роли «угей бала» своего отца («усыновленного»), а быть истинными сынами наших тюркских предков, их огланами. Это - самый главный акцент, который требуется ставить, при

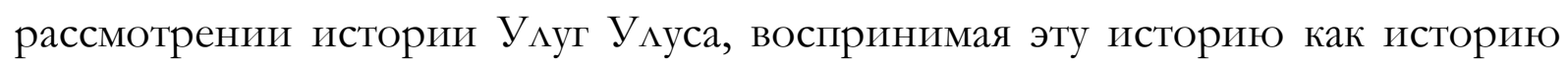
наших славных предков.

Поэтому, актуацьно провести осмысление исторических записок Чокана Валиханова, Машхур-Жусупа Копеева, Абая Кунанбаева, Шакарима Кудайбердиева по их видению золотоордынской истории, восприятия образа Чингиз кагана и его Аинастии, видных представителей тюре. В работе «Несколько слов о корнях происхождения казахов» Абай дает прекрасное объяснение об исторической связи казахов и государством У ууг У уус. В них Чингиз хан не представлен в образе чуждого завоевателя, а, наоборот, выглядит как Алаша хан, который является зачинателем А^ашского тюркского единения.

Из казахских шежире видно, что инициаторами народного Авижения А^аш были Абай, автор «Слов назиданиіи,, Нуржан Наушабай, издавший книгу «Алаи»», и Машхур-Жусуп Копеев, написавший труд о по поводу истории происхождение казахов в произведении «Казах туби» («Истоки казахов»). ИАея Алаш всегда была парадигмой тюркского единства. 


\section{Метол}

Методы исторической реконструкции и интерпретации в изучении истории УАуг УАуса - Золотой ОрАы обусловлены во многом достижениями исторического знания восточных и западных научных школ. При этом, восточные школы, безусловно, оказывали большое влияние на западные, м особенно, на европейскую ориенталистику. Все эти школы и научные традиции, тюркские, мусульманские, китайские, европейские, западные и восточные, которые имели собственный шаблон нарратива исторических событий, искали, изуча^и, понима^и, постига^и сущность государства УАуг

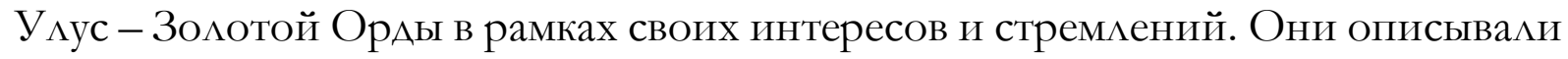
происхожление и политическую природу империи кочевников, культурные особенности тюрко-монгольских народов, феномен туранской цивилизации, специфику хозяйственно-культурной жизнедеятельности.

Востоковеды штудировали тексты арабских, персидских и тюркских источников, прорабатывали Аискурсы авторов, пытались уловить значения, которые имели в виАу историки и современники тех исторических событий. У каждого направления были свои приемы, методы и инструменты. Ориенталисты искали сочинения восточных авторов, осуществ яяии переводы текстов, Аелали комментарий к ним, сравнивали и сопоставАяли разАичные Аанные, события, Ааты, имена, историческую мокализацию.

Археологи искали новые археологические артефакты - свидетельства золотоордынского времени: руины городов, укреплений, поселений и захоронений, следы караван-сараев на путях торговых сообщений, клады монет, образцы доспехов и вооружений. Историки реконструировали хоА исторических событий, общественно-политическую обстановку, раскрывали характер, специфику международных отношений изучаемого времени, характеризовали причинно-следственные связи, выявляли факторы исторического процесса в Центральной Азии. Отсюда скцадывался межАисциплинарный характер методологии исслеАований в изучении золотоордынской истории (А^пысбес, 2021).

Повседневная история кочевников в мирное и военное время, посреАством которой в ней прошлая история приобретает несколько более живой характер, позволяет реалистично смотреть на жизнь акторов истории Укуг Уиуса. Поэтому важно обратить внимание на такие стороны Аанного вопроса, как траАиции семейно-брачных отношений, положении женщины в тюркском обществе, вкАючая военную тактику в условиях того времени, и характер питания, как составной части системы жизнеобеспечения. 
ОтАельно стоит так же вопрос о том, чем руководствовацись те или иные авторы, исследователи, учёные и эрудиты в собирании материалов, изучении истории Золотой Орды, какие существовали заинтересованные стороны, какие задачи и цель они ставили, и, конечно же, начиная от простых чувств мюбопытства, воодушевления и стремления узнать историю Чингиз кагана и становления его государства, присутствовали более прагматичные стороны в этом изыскании, а именно поиск происхождения форм государственного управления, характера политических, Аипломатических, культурных, социальных или экономических отношений общества, обмена и торговли, организации военного дело, армии, форм религии и илеологии.

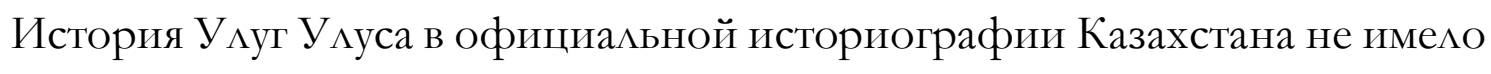
полноценного изложения, поэтому чаще всего освещение этого периода имеет поверхностный, фрагментарный и прерывистый характер, что объясняется существовавшим официальным запретом на исторические исследования этой темы, но исследователи фольклора и традиции устной народной Аитературы занимались им чаще, а востоковеды и этнографы старались продолжать свои изыскания. В академическом издании «История Казахстана» в пяти томах нет Ааже упоминания об эмире ЕАиге, известном деятеле позднего периода золотоордынской истории. Историки, превратившиеся в цеховых истории партии отошли от объективного понимания сути узАовых вопросов национаАьной истории. КажАое из этих научно-исторических направлений имеют свою специфику как в методологии, так и озвучении цели и предмета научного поиска. Тем не менее, более полноценный анализ истории государства Чингиз хана и династии чингизидов была представлена в исследованиях Т.И. Султанова (Султанов, 2006).

Как мы можем заметить, в исследованиях кочевых народов Великой Степи всегда существовац элемент недосказанности, имели место ошибочные умозаключения, неверные трактовки, фальшивые интерпретации, могические нестыковки, искажения. Понятно, что иногда они имели место по причине того, что исследователь не располагал достаточным фактологическим материалом, но в иных случаях, научные объяснения были не верными даже если и имелись конкретные и достоверные сведения в тюркских шежире. Степняки всего мишь немногим ранее, буквально семь веков назаА происходили из тех же поколений тюркских родоплеменных групп, и это утверждение не может быть воспринято как чуждое и постороннее, но как культурно близкое и родственное, в отношении генеалогического происхождения многих тюркских народов прошло всего лишь 50 поколений. 
Казахский историк М. Тынышбаев связывает основные родоплеменные группы, входившие в состав Казахского ханства с племенами Золотой Орды. Некоторые из них относятся к Золотой Орде, но восходят также и к более Аревним временам, к историческому прошлому тюркских каганатов. Казахские шежире, которые он собирал и изучал, сообщают историю знаменитых предков, которые образуются в порядке семипоколенных систем в родоплеменной структуре казахского народа. В этом смысле упомянутая в генеалогическая цепочка предков, восходит к историческим мицам периода Золотой Орды, ко временам провозглашения Казахского ханства. В собрании М. Тынышбаева «Материалы к истории казахского народа» анализируются исторические Аанные о племенах, из которых сложился казахский этнос. На основе этих Аанных рассказывается единая история тюркского сообщества средневековья, образование и смена тюркских государств, их история. Как известно, М. Тынышбаев был подвергнут аресту и пыткам, погиб в застенках сталинских НКВА.

Как отмечает исследователь Аяган Б.Г. «видимо «отцу всех народов» И. Сталину и его сподвижникам не терпелось активизировать процесс ассимиляции народов, и на пути к Аостижению Аанной цели, прежде всего, необходимо было мишить народы исторической памяти. Аействительно, насажАаемый кАассово-социальный подход к изучению истории АишаА нароА исторической памяти. С начала 30-х годов минувшего столетия всё более расширялся список запрещенных по идеологическим причинам изАаний и исторических книг» (Аяган, 2014).

Исследования известного ученого-этнографа, академика А.Х. Маргулана по происхождению этнической истории тюркских племён и содержании эпосов золотоордынского времени, в методологическом отношений представ яют большую научную ценность, так как позволяет взглянуть на это проблематику через наследие носителей этой традиционной культуры. Важно, что он рассматривает их от первого мица (Маргулан, 2007). Он пришёл к теме изучения вопросов истории Золотой Орды с таких научных областей знания, как митературоведение, искусство, архитектура, ориенталистика, археология и этнография.

Изучая через наследие востоковеда Ч.Ч. Валиханова митературные памятники казахского народа, героические эпосы, он раскрыл многие трудные аспекты золотоордынской истории, и чтобы воспринять весь этот объемный материал, требуется соответствующая узко специализированная научная подготовка, и нужно соотнести межАу собой и сопоставить разАичные виды 
исторических источников и культурное наслеАие Великой Степи разных эпох, выявить и наглядно показать их взаимосвязь и культурную преемственность.

Поэтому, наша главная методологическая парадигма заключается в том, чтобы в исследованиях истории УАуг УАуса специалисты Аолжны исходить из первоначальной сути источников, брать во внимание в первую очередь источники внутренние, и Аополнять их затем сообщениями источников внешних, а не наоборот, и не Аопускать вовсе игнорирования тюркских

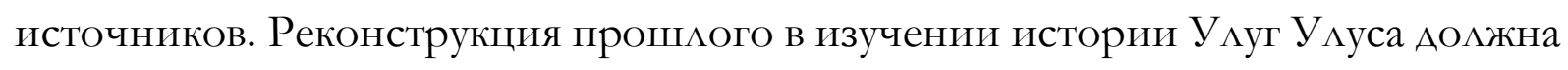
происходить из первоначального понимания событий, сообщаемых шежире тюрков, с вкцючением свидетельств арабских и персидских современников. Это требует от исследователей, в первую очередь, знаний о традиции щежире, знакомство с его содержанием, практические знания о среде его происхождения, бытования, полевые археографические изыскания, сравнительно-сопоставительные исследования образцов и вариантов.

\section{Результаты}

Наши исследования, связанные с изучением шежире казахов и тюркских шежире, показывают, что это явление представ яется самобытной культурноисторической традицией тюрков-степняков, которые в основу фонда знаний положили концепт - Память = Шежире. В рамках шежире транслировалась актуальная информация об истории, топонимике, генеалогии, персоналиях, общественном строе, правовой традиции, политических Аинастиях, родовой организации, родоплеменной герацьдике, этнической антропонимике, и т.А.

А^я кочевников само по себе образ жизни степняка-тюрка, с теми вполне традиционными и укоренившимися исконно фундаментаАьными ценностномировоззренческими установками, которые сложились в Алительный периоА именно вот в таких специфических условиях взаимодействия с окружающей средой, отличающейся зачастую особо суровым природными и климатическими условиями. Шежире является очень Аревней традицией трансляции исторической и генеалогической народной памяти среАи тюркомонгольских племен (Алпысбес, 2004).

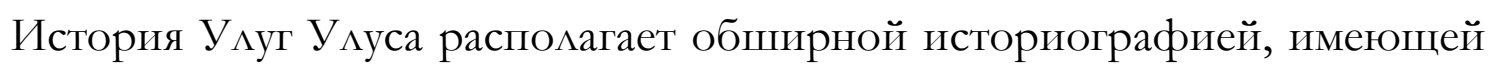
прежле всего отношение к интерпретируемой истории У свою очередь строились на аутентичных материалах исторических источников, объективных научных Аанных. Изучая опыт предшествующих исследователей, следует критически рассмотреть существовавшие и до сих пор устоявшиеся взгляды исследователей, а также следует представить собственное 
виление исторических процессов, фактов и событий, связанных с историей УАуг УАуса, понимание тех или иных моментов объяснений и трактовок, изложенных в источниках. Поэтому, требуется более широкий взгляА, комплексное восприятие исторических процессов Великой степи.

Ааже Аоисторические петроглифы являются одними из безъязыковых исторических документов, рассказывающих об окружающей среле, природе, Аревней жизни и повседневной жизни Аревних туранцев - самом Аревнем периоде обитания Великой степи. В найденных на территории Казахстана петроглифах обозначены извечные символы казахского народа - изображения Солнце и Шанъдак, а также образы различных священных животных и птиц волков, которых они почитади за тотемные существа, мошадей и верблюдов как самых благодатных Аля человека созданий, таутеке, меопардов, танцевальные сцены развцечения, сцены с ездой на транспорте - запряженные телеги, музыкальные инструменты - сърнай, дауылпаз, домбра, кобыз, все они были выгравированы на камне. И даже здесь есть строгая культурная преемственность, не говоря уже о преемственности государства.

\section{Обсужаение}

В метописи Шакарима Кудайбердиева «Старинное сказание казахов о Чингиз кагане» говорится о том, что: «казахи воссаАили Чингиза белую кошму, и подняв его понесли его на вершину «Ханского холма», и таким образом возвели Чингиз кагана в качестве единого правителя на престол. Затем Майки би, казах из рода уйсун Большого жуза, и Сенгене, казах из рода конырат из Среднего жуза зашли к нему. И тогда Чингиз каган дал своим бекам следующие символы власти и атрибуты управления: уран (клич), птицу (геральдический знак), Аерево и тамгу (родовая клеймо, печать). Большому жузу, Майкы бию сказал: пусть ваша птица будет - «Орёл», пусть ваше дерево будет - «Вязь», пусть ваш клич будет - «Салауат», а тамга - «Сурги» (фуганок). Среднему жузу, Сэнгэне бию: кАич - «Коньграт», птица - «Сокол», Аерево - «Яблоко», симво - « Анна». Ао сих пор среди казахов бытует поговорка: «У каждого слова один и тот же корень, изначальныци предок - Майкь Би». Настоящее имя Чингиз кагана - Тэмуджин (Теміриі), Аанное ему имя - Чингиз каган, когда он был избран великим ханом. Это значит очень сильный и великий», - писал он об этих исторических событиях. Таким образом, очевилно, что «искусство звериного стиля сака», берущее начало, очевидно, с традиций петроглифов, имеет не только художественное начало, но и имеет практическое значение, суть которого закАючается в связи межАу тотемом и символом власти. 
МежАу тем, события, подобные избранию Чингиз кагана на Великом Курултае в 1206 году, которое судя по сообщению Абая Кунанбаева имело место в Чингизских горах, откуда произошло переименование этой горы с прежнего названия Найман-Куре на Чингыз-Тау, были в последующем также неоднократно. Аа и в предшествующие времена они, вероятнее всего были не реАки. Абай в своей работе «Несколько слов о корнях происхождения казахов» пишет: «когда на троне воцарился Чингиз каган, казахи приветствовали его. ОАнако Аоподлинно неизвестно, гАе произошла такая встреча. Тем не менее сохранилось предание о том, что в наших Чингизских горах, на побережье реки Караул, расположилось его войско. И по Аревнему закону двенадцать казахских биев из двенадцати родов подняли Чингиза на белой кошме здесь, на горной вершине, тем самым провозгласив его своим ханом. Поэтому горы стали позже называться Чингизскими, а горная вершина - Ханом. ОАним из этих Авенадцати биев был известный Майкы-бий. Сохранилась такая пословица: «Все слова оАного корня, а старейшина этого корня - бий Майкы». Капитан И.Г. Андреев отмечал, что согласно сибирским сказаниям, Чингиз хан был возвышен в ханы среди «киргиз-касаков», т.е. среди протоказахских племён (Андреев, 1998).

Из Аанного сообщения нам стало известно, что в это время уже существовало условное обозначение Старшего и Среднего жузов, которое в науке не признается, но если под жузом понимать значение «дуз» - «степљ», то смыслы «Большая степъ» и «Средняя степъ» вполне согласуется с географической реальностью. Более того, подобного рода значения имеются и в китайских источниках. Уже в политических решениях Чингиз кагана можно найти самые ранние отголоски триальной организации - Үш жүз, которое в Аальнейшем окончательно оформилась у казахов как форма организации хозяйственнотерриториального пространства Степи. Аругим немаловажным фактом Аанного сообщения является то, что Чингиз каган был коронован в традициях интронизации, которые была характерна Аля казахского социума и в последующие времена. Например, одним из таких знаменательных мест является местность «Тангбалы Нура» в пустыне Бетпак-Аала.

Образ Чингиз кагана есть портрет объединителя тюркского мира, политического интегратора - оплот центростремительной концепции воссозАания тюркского могущества. Его политический титул - каган, выражал главный смысл тюркских верховных правителей - глава ханов. В истории гуннов широко известен Модэ шаньюй, или Моде каган, и его титул шаньюй, следует полагать, семантически связан со значением Чингиз. Существует 
разные версии значения этого титула. Рассматривались Ааже обозначение тенгиз - море, или океан. Но это может быть также стяжкой значений шьлн (вершина) $+\mathcal{k}^{3}$ (крутой утес). Кроме того, смысловые аналогии такой титулатуры существует и в предшествующие исторические эпохи. Так, например, титул шаньюй этимологически расшифровывалось как сенгир (вершина). Шань = Сенг в значении вершины горы (каз.: сенгір may - высокая гора), в отношении и значении культа также схож с тенгри, ибо горы в религиях олицетворяют место поклонения и источник Ауховной силы.

Машхур-Жусуп Копеев пишет: «В пустыне Бетпак есть место ТамгаАы Нура, где имеются каменные надписи. Если сыны трех жузов спорят из-за казахских тамг (символов), то они подходят к этому камню, и смотрят на него. Старейшины утвержлают, что тамга была напечатана во времена правления А^аша хана. Говорят, что появившийся в прошлом Чингиз каган также раздал тамги девяносто Авум кипчакам. Мавзолей Алаша хана был построен на западном берегу реки Каракенгир мастерами из Ташкента и Туркестана. ЕАинственный его сын Ажучи в Аетстве ходиц на охоту, и когда его Аошадь вступила в схватку с куланом, то он погиб, будучи проволоченным конем» (Копеев, 1993).

В XV веке кочевые тюркские племена найман, конырат, жалайр и Аругие в периол образования единого союза кочевых племен назвали «казахским союзом». Это слово «казах» имело первоначально не этническое, а социальное значение, и его суть заключалась в следующем смысле: “уметь стойко противостоять внешнему врагу, смело полагаться Аруг на Аруга". Условия жизни тюркских кочевников происходили из системы кровнородственных и родоплеменных союзнических отношений, сформированных жизненными требованиями, которые мегли в основу положений их обычного права. Таким образом, нет какой-либо существенной разницы межАу, скажем, найманами начала XIII века и XV века, в сущности, последние являются их потомками.

Как писал Абай Кунанбаев: «в незапамятные времена от моголов отАелимась одна народность по прозванию татары. Китайцы пишут «татаны». Эти татары и есть незабвенное начало казахов. И в наши Ани выходцы из рода тюре (знать) в спорах межАу собой заявцяют, что они татары. Это означает, что

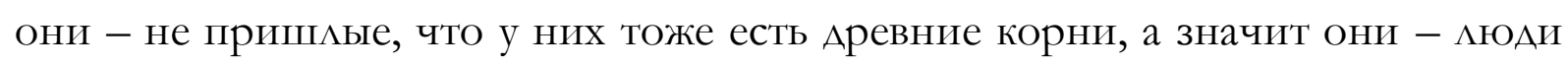
благородные» (Кунанбаев, 2018). В перовоисточниках, например, в работе Рашил аА-дина «Собрание метописей», речь илет не монголах, а о моголах, и это означает, что в искажении основного термина в текстологии источника были весьма заинтересованы рял исследователей. Сейчас это обозначение 
настолько устойчиво оформилась в историографии, что преодолеть привычку будет не так просто, хотя обозначение Моголистан, а затем, и название государство Великих Моголов, было и значительно позже.

Противоречивым в истории государства Чингиз кагана, Укуг УАуса, является вопрос завоевания и порабощения. Понятное Аело, что монголы (или могулы, согласно первоисточникам) будучи частью, или как это отмечено у Рашил аА-Аина «суть незначительная ветвь тюрков», являлись завоевателями на территории Ирана, Китая, и Ааже Маньчжурии, не говоря уже о Руси и странах Восточной Европы, но ведь они не могли быть завоевателями на собственно тюркских территориях, если же они были частью этих самых тюрков. Из источников известно, что когАа они - могулы, согласно сообщениям источников, прибыли на земли кыпчаков, то они заявили им, что они оАной крови, то есть одного происхожАения, и значит они упоминали культурноисторическую схожесть, общее этническое происхождение в качестве представителей тюркского эля под властью киятов. ЗАесь, скорее всего, следует рассматривать противостояния межАу удельными владетелями и Чингиз каганом, который стремился объеАинить тюрков.

Представление о том, что моголы Чингиз кагана пришли в Хорезм как завоеватели, также не совсем верно. Известно, что кыпчаки Сырдарьинской части или юга современного Казахстана на тот период подпали поА доминирование-угнетение государства Хорезмшаха Мухаммеда. Обозначение «шах» является титулатурой персиАской, а не тюркской политической элиты, т.е. политически и этнически чуждой страны. Историко-географический регион Трансоксании не может рассматриваться Аишь, как искцючительно ирано-согАийское этнокультурное пространство, зАесь веАь изАревле присутствова^и тюрки, как исконные обитатели, из их числа такие известные сообщества как - канглы, кипчаки, асы, и Аругие. Поэтому, концепция «кризиса сложения народностей» вовсе не вылерживает критики. Государство Чингиз кагана стацо объединительной силой разобщенного на тот момент тюркского мира, одна часть которого подпаца под зависимость Китая, а Аругая часть оказалось в зависимости от воли могущественного Хорезмшаха, находившегося к тому же под тяжелой пятой исмаилитских сект. Например,

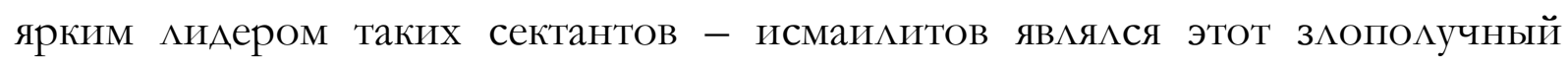
Ажалац-аА-Аин, сын Хорезмшаха.

Многие авторы раньше писали, что при всех победах войск чингизидов, их военные походы негативно сказалось на политическом, экономическом и социальном развитии тюркского населения на территории Аешт-и Кыпчака, 
что были разрушены присырдарьинские и жетысуйские города Центральной Азии, что Аля подав ения сопротивления местного населения, «монгольские захватчики» применяли чуть $\Lambda и$ не «тактику выжженной земли», что истребляли целые населенные пункты, которые не желали подчиняться новой власти, и что такие разрушительные Аействия наАолго прервали естественное сложение многих народностей, что чингизиды на покоренных территориях закрепили «монгольские феодальные традиции», разделили завоеванные страны и народы на отдельные улусы, во главе которых стояли потомки Чингиз кагана, а господство тюркской аристократии установилось не только в Аешт-и Кыпчаке, но также в Китае, Сибири, Центрацьной Азии, Ближнем Востоке, России и в странах Восточной Европы.

Шакарим Кудайбердиев писал: «роды могли входить в разАичные союзы, целиком и частями, но Аолжны были твердо сохранять свои исконные имена. И в самом деле, как увидим, родовые имена, записанные многие века тому назал китайскими историками, конечно, вследствие политического значения носивших их родов, сохраняются частью и поныне. Это обстоятельство Ааёт возможность определить в значительной мере этнический состав тех из ныне существующих тюркских племен и народностей, которые сохранили кочевой образ жизни, родовой быт, и родовые имена» (Кудайбердиев, 1990).

Основные племенные названия казахов почитаются как Аревние родовые общины, и что они были яАром Аревних государств. В этом смысле суть казахской историко-генеалогической памяти в рамках шежире преАстав яется совокупностью сложения основного социума, являющегося носителем государственности. Встречаются примеры родовых названий казахского народа, которые были известны еще в глубокой Аревности. В свое время они вступали в состав родоплеменных объединений, заключали военнополитические союзы, менявшие свою конфигурацию в разные исторические эпохи. Это связано с тем, что степные сообщества всегда носили наследственный и Аинастический статус своих сообществ, чтобы учесть количество и размер сообществ в военной организации в рамках своих социальных структур.

Историческое повествование Абая Кунанбаева строится на понимании того, что предки казахов, в период истории становления государства Чингиз кагана, всегда были в центре этих самых событий, и свидетельством тому, служат народные поговорки и пословицы, которые как наиболее компактная форма передачи информации на протяжений целых столетий откладывались 
в колмективной памяти народа из века в век, сохраняли суть происходивших событий, а самое главное, они были сообщены самим казахским народом.

Абай Кунанбаев пишет: «вначале был убит Гурхан, (то есть найманский Кучлук хан, принявший на себя титу киланского правителя), захвачено племя уйгуров (которое в то время действительно было под властью Кучлука), а затем войско продвинулось в глубь Азии. Об этом свидетельствуют такие казахские пословицы, отражающие походы Чингиза, как: «В гоА Змеи была жара, в гоА Аошади было сражение, а в год Овцы - большое перемирие», «Просторна дорога Самарканда, узка дорога Буланая. Под Буланаем, очевидно, подразумеваются горы Гималаи или Гиндукуша. Речь, по-видимому, идет о горах. Об этом нам известно по такой пословице: «Нет гор больше Буланая, нет животного крупнее мося - булан. Впоследствии эта часть казахов, оставив горы А^атау, обосновалась у подножий гор, расположенных вокруг Ташкента. Аоподиинно неизвестно о том, сколько их здесь было, где обитали раньше, а где - позже. Когда они прибыли в эти места, то оказались под вАастью прямого потомка Чагатая, одного из сыновей Чингиза» (Кунанбаев, 2018).

М. Тынышбаев в статье «Тюрко-монгольская история» писал: «Обиталище и потомки знаменитого Чингисхана до сих пор находятся среди казахов. Армия и вся страна, находившаяся во власти Хулагу хана, завоевавшего Иран, в основном состояла из жалаиров. Османские тюрки Стамбула являются выходцами из канглы. В VI веке в Монголии был собственный уйгурский алфавит. Махмуд Кашгари в 1069 году в городе Баласагун (близ города Токмак) написал труд «КутаАгу билик» («Благословенная власть» - автор) на уйгурском языке. В XII-XIII веках уйгуры писа^и историю, философию и многие Аругие произведения. Китайские правители приглашали уйгурских ученых редактировать свои книги. Внук Эмира Тимура, знаменитый Уиугбек был первым астрономом своего времени, и сегодня в Самарканде сохранились остатки обсерватории У уугбека. Эти пять-шесть примеров ярко показывают культурные достижения тюрко-монголов».

Большое значение имеют заветы Чингиз кагана, смысл которых, устойчиво транслируется гораздо позже в традиции степного Кодекса уложений казахов. Анализ смыслов и содержания «Ясы» (Жасак, каз. «Жолжосын»), а также билики (знания), например, вплоть до ХІХ века были в основе государственных экзаменов в Китае, для занятия чиновничьих рангов, хотя уже Аавно не было империи Юань. Сюжеты мифологической интерпретации образа Чингиз кагана сохранились в исторических преданиях казахов, 
известны по собраниям Машхура-Жусупа, которые были переданы им затем Г.Н. Потанину и В.В. Рацлову (Көпеев, 1993).

В историческом фольклоре казахов встречаются такие определения, как «Аесять сан оймаутов», «девять сан торгаутов», «тридцать сан римлян», «Аесять сан ногаев», Следует пояснить, что в традиции исчисления у тюркских народов значение «сан» соответствует числу «сто тысяч», а значение «множество» или «бесчисленное количество» выражается в значении «тумен», что означало условно «десять тысяч человек». Таким образом, «десять сан» означает «один

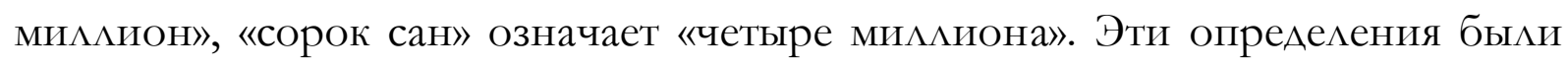
Аемографическим показателем населения в то время и мерой того, насколько могущественной было государство, насколько Аемографически сильной была страна. Во времена Абылая населения Среднего жуза составляло «десять сан», то есть мициион человек.

Чокан Валиханов в своих научных исследованиях писал, что согласно сообщениям КаАыргали Жалаири в его «Собрании метописей» говорится о «Ногайльнынг ауъгр журтьл), т.е. «Могущественныгй (очень сильный) юорт (обиталище, население) ногайлинев», основой Аця такого обозначения стало именно факт правления беклярбека Ногая (1235-1300). Он был сыном Татара, который был сыном Могола, который был сыном Бугала (Бууала), т.е. Ногай был внуком Буга^а (кстати, его имя может быть прочитано как Мугац, и Аействительно, в Аругом источнике отмечается, что Ногай, сын Татары, сын Могола, сын Чингиз кагана), седьмого сына Ажучи. Это показывает, что живая традиция называть детей именами далеких предков всегда, была устойчива в культурной среде тюрков. По такой же причине сейчас у казахов существует традиция имянаречения, Кыпшакбай, Аргынбай, Найманбай, и т.А.

Истории государства УАуг УАус стала квинтэссенцией политического и культурно-идеологического выражения степных империи гуннов и тюрков, то есть преломление траАиций ранних империи тюрков в новую региональную Аержаву - Казахское ханство. Это показывает историческую роль традиции самоорганизации кочевников. УАуг УАус является своего рода фокусом истории Великой Степи, через которое отражаются все Ауховные, культурноцивилизационные, политико-правовые, социальные и духовные процессы в истории прототюрков и тюрков, протоказахов и казахов, в промежутке межАу Аревностью, средневековьем, новым временем и современностью. История

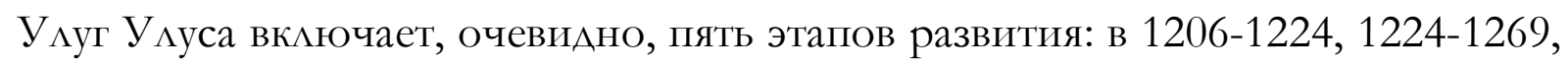
1269-1312, 1312-1392, 1392-1428 годы. 
По мнению Ч. Валиханова, «курлеуты были Аревним монгольским племенем и теперь они состав яют ветвь кипчакского племени среАи казахов». История племён катаган и коралас также схожа с историей курлеутов. Аевшин в своих трудах высказац мысль, что казахи явцяются тем политическим еАинством, которое образовалось в результате союза различных монгольских и тюркских родов и племен эпохи Золотой и Чагатайской ОрА. Ещё раз следует отметить, что когда речь идет об этническом обозначении монголов, то это о моголы той исторической эпохи. В трудах РашиА аА-Аина говорится, что моголы на самом деле были незначительной ветвью тюрков. Этот исторический факт не противоречит реальности, и согласуется с историографией того времени.

Применительно к степным тюркским народам следует говорить не о завоеваниях, а подчинениях, как, например, уже бывало в истории, когда карлуки, скажем, подчинили тюргешские племена, а кыпчаки - огузов; могулы найманов и кереев, и т.А. (Кадырбаев, 1992). Это связано мишь с возвышением какой-либо отАельной части, племени или конфедерации родов или ветвей тюрков. И зАесь, как вилно, происходила трансформация государств, чаще ее объясняли как «падение» или «исчезновение», но было, возможно, это было падение династий, правящих политических кланов, но не исчезновение государственности, как таковых.

Государство Чингиз кагана было воплощением заветной тюркской илеи единой тюркской страны «войлочностенного народа» - государства «киіз туъдлытктылардън еліл, что выражает значение воссоздания былой славы кочевой степной империи небесных тюрков (Кок тюрик) - народа Аревних степняков-коневодов, наследников эфталитов, гуннов, кангюй-канлы, хьонкиятов. И это выражает тот знаменательный факт истории, что менталитет, культурная самобытность и цивилизационная идентичность степняков, которую сейчас принято называть этнической, была утверждена уже могуществом тюркских каганов, но, возможно, поА пагубным воздействием внешних сиц, злонамеренным влиянием разных илеологии, преследовавшим цель разобщения тюрков, противопоставления их Аруг против Аруга, формирования междоусобицы Аинастий, обособления на раздельные тюркские государства и дальнейшего их разАробления на мелкие в адения.

Абай Кунанбаев писал: «Именно арабы прозвали кочевые народы именем «хибаи» или «хузаги». САово «хибай» означало, что мюАи пользуются войлочными шатрами. А слово «хузаги» было связано с тем, что в их родных краях также под таким названием проживало кочевое племя. ОАин из ханов, 
увилев вербцюжий караван кочевников, сравниц его с перелетной гусиной стаей: «Вот эти АюАи - Аействите ьно казахи», (то есть связывает имя казах со значением “каз”). Так эти кочевники и стали сами себя называть «казахами». Аругие племена восприняли сие название, хотя прежде себя называли

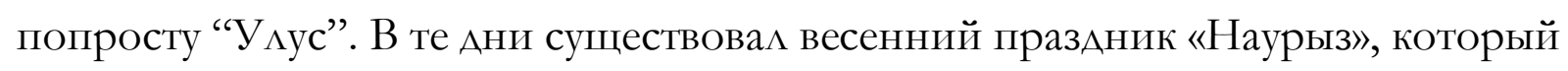
казахи кочевники очень мюбили и называли великим Анем государства. В наши Ани это слово соотносят с мусульманским праздником “Курбан-айт”. После принятия новой религии произошла замена старых названий городов, кроме Бухары, земель, озёр и рек и даже отдельных народов. Похоже, так и происходило. Как бы там ни было, с тех пор мы и стали называться казахами».

В китайской историографии тюрки в окрестностях Великой Китайской стены расселялись белые татары. В основном влаление Басмылов (Басими), ханство Онгутов. Западнее них располагались черные татары. Это Аолжно быть Жалайъг, Найман, Керей, Карлуки, затем, так называемые дикие татары. Как отмечац Абай Кунанбаев, «эти татары, оказывается, воинственны, увлеченно занимаются охотой, носят и едят что придется, веАут дикий образ жизни. Они расселялись и заняли местность в верховьях рек Енисей и Ангара. По их обыкновению, охотники уходили от своего поселения на один гоА, и даже на Ава. Позже охотники стали говорить об увиденных ими земАях, где зима бывает короткой, а мето - Алинным».

Затем, Абай Кунанбаев утвержАает, что они имеют сходство с казахами: «в восточной части Сибири живут собратья казахов, которые еще не вошли в ислам. Тем не менее, ясно, что они родственны казахам по языку, по обычаям, и по облику. Особенно близки казахам так называемые «ясачные татары», народность в Минусинском крае, на Енисее. Говорят, что и они казахов считают своими собратьями, и при виде их никто не смог бы возразить против наличия сходства межАу нами, наших очевидных родственных связей. Ни один казах не стац бы возражать против утверждения, что казахи и киргизы родственные между собой народы. Этих самых киргизов называют «бурутами», однако мне не удалось встретить в истории объяснений, почему в китайских известиях называли их «брутами». Казахи называют проживающих в окрестностях Бийска и Кузнецке калмаков «блеут». И по моим предположениям, эти «блеуть»» и «буруть»» имеют общее происхождение, и исходят от одного и того же названия. Соответственно, немудрено, что они произошли от кыргызов».

Нужно также отметить, что многие известные образцы тюркского фольклора всегда бытует среди разных тюркских народов. Например, «Козы- 
Корпеш - Баян-Сулу» одинаково близки как казахам, так и саха-якутам. Сюжет эпики относится, по-видимому, к гуннскому времени, как это показывает архитектурный памятник, характер строения самого мавзолея. В номенклатуре исторической генеалогии казахов фигурируют наименования Аревнейших тюркских общин, которые на пути становления нации, всегда вкАючали такие группы тюркских народов, как огузы и кипчаки, кияты и коныраты, басмилы, карлуки, караханы, кимеки, Аругие Аревние образования.

Что касается Аинастических структур и генеалогических традиций казахского народа, он начинается с исторических знаний Аревних тюрков, казахских мегенд, таких как «Огуз-нама», «Коркыт-Ата», «Козы-Корпеш-Баян Сулу», «Ер-Тостик». Все они являются первоисточниками национальных исторических знаний, относящихся к категории историко-культурного наследия, о котором веками говорят в народе. Эти исторические произведения эпического характера содержат сведения об известных Аревнетюркских Аеятелях, мировоззрении, истории повседневной жизни, философии, религиозных верованиях, именах Аюдей с географическими названиями, родоплеменной структуре, внешних и внутренних отношениях.

М. Тынышбаев в своей статье «Тюрко-монгльская история» в первом номере журнала «Сана» за 1923 гол писал: «в древнейшие времена тюрко-монгольское сообщество были знамениты на весь свет, с незапамятных времен гунны, покорившие китайцев, подчинившие своей власти все тюрко-могольское пространство, а затем завоевавшие Европу, они произошли от тюрков. Ханы, которые привели булгар к Аунаю, также были выходцами из дулатов. Кипчаки и каракалпаки, некогда изрядно тревожившие Россию, являются составной частью тюрков».

Как мы виАим, в историческом самосознании казахов конца XIX - нач. XX века, например, у Чокана Валиханова, Машхур-Жусупа, Абая, Шакарима, Мухамеджана Тынышбаева, и других история происхождения казахов уходит вглубь веков, и оно не ограничивается Аишь временем образования Казахского ханства, и такой взгляА он совершенно ясен, ибо все те тюркские родоплеменные образования, которые составили казахский народ, они были в историческом прошлом и за много веков раньше. Поэтому, Машхур-Жусуп использует такое определение «это было в те времена, когда казахи еще не проявились в качестве казахов», а Шакарим использует условное понятие «Аоказахские времена» как «протоказахская эпоха», то есть казахи уже были тогда в истории, но они фигурирова^и чаще в своих предэтнонимах. 
Так, Абай Кунанбаев пишет: «Аюди, издревле привыкшие к разведению коней и овец, стали заявАять: “Мы переселимся в те края, которые удобны Аля животноводства”. Так они постепенно стаци менять место проживания. Частью этих Аюдей были наши предки - казахи. Неизвестно, какими путями и за сколько мет казахи прибыли в эти края. Все же вскоре они Аобрались Ао скцонов А^атау и остановицись там на постоянное жительство. Они не могли Авинуться Аальше, поскольку Аалее была земля, издавна приналлежавшая уйгурам, которые там уже прочно укрепились. Хан этого уйгурского сообщества держал пол строгим учетом подвластное ему население. Пришлые же, хоть и признали его вцасть, тем не менее отнеслись к нему не Аружелюбно. Испокон веков казахи как свободолюбивый народ считал Аля себя, подчинение кому-либо, тягостным бременем. Уйгуры сами были выходцами из могоцов, но кочевников они считали чужими».

В рассмотрении империи Чингиз кагана важно изучить такие вопросы, как письменные и устные предания (щежире) в качестве исторического источника, племена в империи Чингиз кагана, система прав, власти и суды, особенности культуры, язык и военное искусство кочевников, вопросы религии и отношении к нему в УАуг УАусе как вопрос государственной идеологии и внешней политики государства. Как известно задача всякого историка заключается в умении очень внятно и по возможности более Аетально объяснить хоА и развитие исторического процесса, и связать исторические события в могическую взаимосвязь, как результат принятых

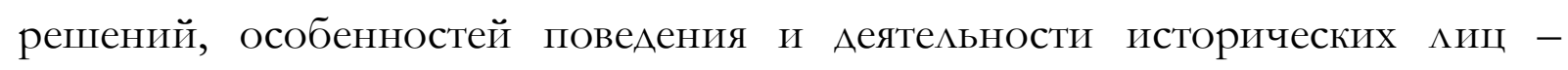
конкретных мичностей, от которых Аействительно зависели те или иные социально-экономические обстоятельства жизни всей страны или военнополитическая история государства. Рассматривая все эти вопросы, мы изучаем их как маркеры, позволяющие определить культурную принаАлежность того или иного феномена по внешнему и внутреннему характеру его прояв ения.

Согласно исторической памяти - шежире казахов, Чингиз каган имел титулом Алаша хана, значение и знак, этимология и семантика этого понятия сопряжено с такими традиционными категориями, как - алаш (алашък), т.е. мачуга, иначе говоря переносное жилище, состоящего из жердей унины (уыл), укрюка (куръгк) или копья (найза), покрытого куском войлока, служившего Аля воина и/или коневода, временным укрытие или кровом, прообраз юрты (кийз yü) - самый основной символический элемент тюркского мира, вкАючающий такую чрезвычайно важную категорию как шанырак, символизирующее и отчий Аом, опору и крепкую семью (omay), Аинастию (аулет) и даже основы 
целого государства («шаныракка кара», буквацьно, «обрати внимание кто хозяин в доме»); алаша - Аомотканный грубошерстный ковер из шерсти, сочетание разноцветных полос этого паласа, выражает семантику соединения самых разных общин - племён и родов, состав енных в еАиный эль.

Как известно, орнаментика мавзолея А^аша хана связанная с особой техникой кладки кирпича, напоминает традиционный казахский палас - aлaша, характеризующийся сочетанием пестрых цветов, семантически выражающее значение соединения, единения. Все эти культурные коды чрезвычайно важны. В истории Аревней Азии степные народа сака и гунны преподнесли пример создания мощных государственных образований, путём объединения крупных племенных союзов в единое государство.

И по этому примеру происходило формирование первых китайских государств. Схожим же образом и в последующий период, как виАим, происходило единение разрозненных этнических групп Европы в политически более консолидированные союзы, в государственные объединения, в конечном итоге приведшие к сложению наций. Поэтому, концепция о «Аолгом прерывании естественного сложения народностей» не вылерживает критики по той простой причине, что утверждение о монголах, или могулах, что они были крайне «жестоки и беспощаАны», Аолжны быть тоже переосмыслены, по-новому рассмотрены и оценены в Аетацях.

История военно-политической деятельности, государственного почина,

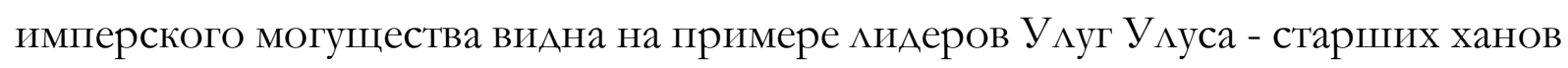
Бату (1208-1256) и Берке (Беркай, Берке-Оглл, 1209-1266), темник Ногая и Узбек хана (1283-1341), Жаныбека (неизвестно-1357). В книге Утемиша хаджи «Чингиз нама» есть сюжет о том, как сыновья Ажучи - Орда-Ежен и Бату взаимно отказывались от политической власти в пользу Аругу Аруга, что отражает целый рял ценностно-цивилизационных мотивов степняков (Утемиш хаджи. Чингиз-наме, 1992). Но в последующем, некоторые моменты истории У уу Ажучи отличаются тем, что наступает великая «смута» в Орде». Некоторые исследователи связывают это с историей факторах исламизации

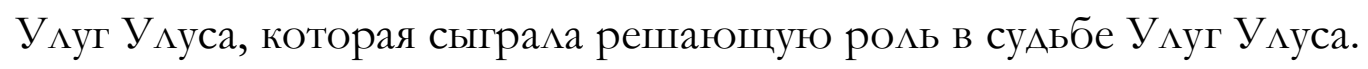

Имя Ногая и имя Узбека стали в истории эпонимом целых этнических сообществ, например, население Улуг УАуса - Золотой Орды называлось, согласно шежире, ногайлы (подчеркиваю, не ногай). Отсюда следует что он был Ажучидом, но в силу того, что он родился от младшей жены, а не от старшей, то соответственно его права на наследие отца были усечёнными, согласно традиции. Или правильнее сказать преданным и налёжным союзником 
Ажучилов (по меньшей мере Берке хана), однозначно - он был чингизидом, и туменбасы (от этого слова происходит русское понятие темник - М.A.) командующий начацьник наА Аесятью тысячью воинами. МежАу прочим, Берке хан поручим под его знамя Ааже не один, а несколько туменов. О происхождении Ногая исследовал у Н.И. Веселовский в работе «Хан из темников Золотой Орды и его время» (Веселовский, 1922). Имя Узбек хана как эпоним трансформировался позже в этноним, от мица которого произошли имена собственно целого сообщества, известного из шежире как «девяностодвухстоставный узбекский улус» («токсан екі баульг узбек»), «mридуатидвухсоставный улус узбеков» («токсан екі баульг узбек»). Исходя из того, что существует анацогическое обозначение токсан еки бауль кыпшак (отыз екі бауль къппиак), можно слелать заключение, что весь основной этнический колцектив Аешт-и Кыпчака, преобразовался в единый Узбеков УАус, или кочевое государство Узбекия, которое затем преобразилось, соответственно, в узбекказахов.

Из этих сведений шежире казахов мы можем слелать следующие заключение: казахи, или правильнее было бы сказать, представители Аесяти ведущих племен, которые позже составили основной костяк казахского союза сформировавшей казахскую нацию, находились практически в составе всех четырех улусов на велущих позициях, как большинство их населения. У уус Ажучи при ханах Берке и Узбеке усилил позиции как государства. Чагатаев улус был менее могущественен в плане устойчивости ханской власти, и оно в конечном итоге обернулось усилением Эмира Тимура и потерей управления улусом представителями политической элиты чагатаидов в пользу Тамерлана.

Вот что пишет Абай Кунанбаев: «главный хан из потомков Чагатая жиц в то время в Ташкенте, а казахами правиц один из его младших братьев. В этот период процветали угон скота - барымта, разбой аулов, вражда племен. Аюди жили бедно, не наблюдацось численного роста казахов. Ведя себя по принципу: «Приходит как смелый Ажигит, а убегает как собака», АюАи не умели Ааже правильно оберегать себя и свой скот от врагов. Увеличение численности казахов, по-видимому, происходит после разрушения калмыцкого общества и только после обоснования на Сары-Арке. Не случайно появляется и выражение: «Отняв у врага девушку, обзаведешься женой, а убив старшего брата, женишься на своей женге (жене старшего брата)» (Кунанбаев, 2018).

Сакен Сейфулиин в своей книге «Краткая история казахской митературы» писал: «Земли к запаАу от него перешли к Угедею... После смерти Чингиз кагана великим ханом стал Угедей. Земли к западу от Аоли Угедею являются 
Аолей Чагатая. К западу от него (самый западный край) Черного моря до Руси УАус Ажучи. Все эти Аоли четырёх сыновей Чингиза принаАлежали тюркским племенам. В те времена сообразовались тюркские племена, ставшие впоследствии казахами в частях Ажучи и Чагатая. Некоторое время спустя тюрко-монгольские племена Чагатая переселились в УАус Ажучи. После перехода этих племён от Чагатаяв к Ажучи, в их состав вошли тюркские племена, известные как современные казахские племена: Жалаир, Канглы, А^шин, Кипчак, Конырат, Мангыт, Уйсун, Аргын, Найман, Керей и Аругие. Таким образом, тюрко-могольские племена, сформировавшиеся как современные казахи, в то время принациежали Ажучи-хану, который распространился от Крыма до Волго-Урала, Восточной Сибири, КаратауА^атау. Ажучи умер раньше Чингиза. Аоля Ажучи досталась пятерым сыновьям Ажучи: Ежену, Батыю, Береке, Шайбаку, Токай-Темиру. Орда Запада называцась Золотой Ордой» (Сейфулиин, 2007).

В источниках близкой к тем временам эпохи, например, в трудах M.X. Аулати и Аругих авторов, отмечацось, что при создании Казахского ханства, первоначально было двести тысяч населения, которое затем в период Касым хана количество казахов насчитывало свыше миллиона человек. Численность населения и его рост был связан в это период не только с Аемографическими показателями рожАаемости, но и перемещением населения. Родоплеменные сообщества, которых мы называемым по примеру академика А.Х. Маргулана протоказахскими и казахскими племенами, они переходили из состава одного удельного владения чингизидов в Аругое, как говорится в преданиях народа, отложились в его пословицах и поговорках из Крыма в Рум, то есть земли от Крыма до Стамбула, от Китайской стены до Трансоксании, пространства Великой степи и сопредельные земли находились в ведении кочевнического тюркского сообщества - огромного конгломерата больших тюркских племен - девяностодвухсоставного большого кыпчакского объединения, называвших себя как ногайльг кьгпшак, девяностодвухсоставного узбекия. Собственно, в элементах жуза уже присутствует отголоски той былой улусной пространственной системы.

Абай Кунанбаев, опираясь на сообщения тимуридского эмира Бабура, пишет: «Из родословной Тамерлана: у матери известного царя Бабура, сына Гумар Шайха, было два родных брата, один из них был ханом Ташкента, а Аругой был возвышен ханом казахами. Они были сыновьями хана Юнуса, родословная которого берет начало от Чагатая. Того правителя казахов звали Ахметом. Вот он в свое время из казахов, наиболее пригодных к военному походу, составиц и три жуза воинов, которыми командовали жузбасы. 
Представители каждого жуза считались между собой родственно связанными воинами. Отсюда и пошло выражение: “Аети трех жузов". Хан Ахмет часто совершал набеги. Каммаки из-за его жестокосердия, вместо того чтобы сказать: “жан алуши” (душегуб, палач), говорили: «Этот прямо-таки стац “алаши”. Поэтому своего правителя прозвали «хан Алаша». Так написано в «Бабур-наме» (Кунанбаев, 2018).

В ходе процесса исламизации УАуг УАуса определенная часть тюркских племен оставалась в своих доисламских воззрениях. В связи с этим наметился раскол единства, которое в шежире получило условное название «казак-калмак айъцыллан» - «время раздвоения казаков-калмаков», то есть часть тюркских племен, не пожелавшая принять исламское вероубежления, которое в это время стало уже преобладающим в степном пространстве, получили название калмак, то есть «отколовшиеся», или дословно «оставшиеся вне». Это такие тюркские племена как чор, чоросы, торгауты (возможно, ранние тюркюты), Аорбуты, хошоуты, и Аругие, которые имели некогда, вероятно, генетическую связь с кереями, меркитами, найманами, жалаирами, и т.А., в более отАалённые времена. Это приводило к новым формам Алительного внутреннего противостояния.

«Вскоре в Среднюю Азию прибыла многочисленная армия арабовмиссионеров с целью распространения ислама. Известный в то время активный приверженец ислама Кутайба дошел до самой Кашгарии, обращая население к исламу. Кочевники тоже объявили себя мусульманами, хотя долгое время не порывали со своими Аавними представлениями о об устройстве мира: признавали баксы и предсказателей, преклонялись перед огнём и светом. В те времена человека, мало-мальски овладевшего грамотой, называли «абызом» учёным. Чаще всего, так называли мул -священнослужителей. Преклонение шаманизму мы находим в отдельных обрядах, когда Аюди, не умея объяснить причины тех или иных явлений, считали, что их ниспослал Бог. Так, например, во время первого прихода невестки в дом своего жениха родственники мили масло в огонь со словами: «Огонь - Мать! Масло - Мать! Аай нам благодать!». И^и зажигали светильники, говоря при этом: «Посвящаем Ауху покойника». И^и же, во время первого весеннего грома, женщины громко ударяли ковшами по стенам дома со словами: «Молока много, а угля мало». Подобных обрядов было много, но ныне, слава богу, похоже, что они забываются».

В этот период тюркской истории происходицо этническое разобщение межАу разАичными группами тюркских племен в связи с религиозным разобщением - переходом части тюрков в мамаизм, а Аругой части в шиизм. 
Эти процессы внесли раскол этнокультурное тюркское пространство, но казахи в рамках своих национацьных стойких убеждений и сложившейся в рамках учений Ходжа Ахмеда Яссави, Жусупа Баласагуни, Махмуда Кашагри, трудов Низами, философии степных мудрецов-импровизаторов, жырау, бишешен, абызов, воззрений Асана Кайгы, и Аругих мыслителей, сохранили самобытную ценностную систему и противостояли внешним религиозным вАияниям и силам, способных подорвать национацьное еАинство.

Абай Кунанбаев отмечает: «хан, смекнув, что кацмаки так отзываются о нем из-за страха, приказац своим воинам, чтобы во время сражения они громко кричали уран (клич): «алаш-алаш». ОАнако при сплошном шуме стало слышаться: «алаш-алаш». Поэтому распространицось выражение: «Что только мы не делали с калмаками, когда были алашами и правиц нами хан Ацаша». ТогАа эти казахи относились к потомкам Чагатая. Узбекскими же племенами правили потомки Ажучи. Вскоре среди потомков Сибана или Шибана, сына того самого Ажучи, выдвинулся известный хан по имени Шайбак, который стал постепенно отнимать у потомков Тамерцана города Герат, Бухара, Самарканд. Против него, наконец, Авинулось многочисленное войско хана А^аши, воссоединившегося со своим старшим братом Жамке. Но войско потерпело поражение на Ура-Тюбе, воины были убиты. Казахи перешли в ведение Шайбака и подлержали его».

Вопрос мокализации территории, месте становления государства Чингиз кагана, а затем и Уиуг УАуса, многие исследователи считают вполне ясным и решенным, тем не менее отдельные выводы выглядят натянутыми и противоречивыми. Утверждения, что Чингиз каган и его полчища разрушили многочисленные города, в основном особенно мрачно сообщали персилские историки, и по их следам мусульманские, арабские авторы, на труды которых в основном ссылались французские чингизхановеды, и писали об его империи. В ряде источниках сообщалось, что Чингиз каган извец Ао восьми десятой части населения Персии, но оракул и очевидец тех мет Чан-Чунь Цю, совершивший трехлетнее путешествие из Ханбалыка до Самарканда, неоднократно пересекал реку Амударью. В своей книге «Сиюйцзи» он подробно рассказывает об этих местах, которые в течение путешествия автор повидал, с 1219 по 1222 годы (Акишев, 2004).

Все пределы страны Чингиз кагана, начиная от современной Монголии, А^тая, Семиречья и Мавераннахр, он обошел сам и подробно сообщает о цветущих садах и городах, не упоминает он о каких-либо разрушенных городах. Он вилец своими глазами города Алмалык, Койлык, Сайрам, и другие. 
Поэтомуғ все это исходит Аишь от мстительности побежАенных народов и их представителей по отношению к насельникам УАуг УАуса и Великой степи. Свою книгу воспоминаний Чань Чунь Цю о путешествии писал уже по возвращении, и рукопись еще долгие века оставалась не прочитанной, без всякой цензуры, и ему не мешало ничто, если бы он хотеА написать всю правАу «О страшных разрушениях городов».

По обнаруженным источникам заметно, что татаро-моголы были веротерпимы, не стремились к насильственной ассимицяции покоренных народов, хотя и могли с Аегкостью это сАелать, и по какой причине они вАруг оказались виноваты в «прерывании сложения народностей»?! Татарская экспансия происходила по тем же естественным, географическим транзитным путям, по которым раньше совершали передвижения и перемещение скифы сака, киммерийцы, а затем тюрки, способствовацо культурной контаминации, близкому взаимодействию многих этносов, результатом которого становились формирование новых народов. И они стимулировали этот процесс этнообразования, также как и Аругие явления и процессы в экономику, культуру, хозяйственную жизнь, торговлю и обмен. Тюрки были и в Китае, и в Иране, и в Индии (Кадырбаев, 1990).

Следующим элементом в развитии истории УАуг УАус стало проверка на устойчивость института чингизидов, правоустанавливающая верховенство потомков Чингиз кагана и Ажучи хана. Их наследник получили статус тюре. Это право наделяло их новыми функциями арбитра - верховной нейтральной политической силы межАу степными тюркскими племенами. ОтАельные группы политической элиты степных племен стали оспаривать господство чингизидов, отходить от признания их верховного имперского права. Это также свидетельствовало о назревании сепаратистских тенденций, раскола в среде единого, некогАа воссозданного после тюркских каганов вновь, Чингиз каганом монолитного тюркского сообщества. Появцяется народная мудрость «болюнгенді борю жейді», буквально «отошедшего раздельно съест волк», т.е. смысл заключался в том, что только единство тюрков является гарантией свободы и безопасности всего тюркского пространства. Этот период истории в шежире получило условное название «казак-ногай болюнген», то есть «раздвоение казаковногаев», когАа ногайские мурзы, желая установить свое единоличное правовое и политическое господство стало отходить от признания верховенства тюречингизидов. Но казахи сохранили институт чингизидов в Казахском ханстве.

«Ао сих пор бытует выражение: «Мы изначально были родственны с узбеками, так как Чингиз каган еще при жизни определил в Унус Ажучи. Как 
говорится, «узбек - собрат наш, а сарты - чужаки». После этого потомки Чагатая никогда не восседали на казахском троне, только потомков Ажучи торжественно поднимали на белой кошме, и он становицись нашими ханами из тюре, потомков чингизидов», а трон, как следует понять, он изначацьно бы казахский, так как отметили выше, Чингиз каган был избран в статус Великого кагана Авенадцатью казахскими биями, согласно казахским преданиям. Эти факты, которые излагает Абай, показывает, что основная часть казахских племен в последующем входила в состав У ууса Ажучи. И они были не только источником, но и подвижниками Чингиз кагана.

Абай писал: «В то время кроткие и спокойные казахи придерживались пословицы: «Отвергнувший Аух покойного станет непутевым». Пословицы же: «Аобыча смелого Ажигита и Аобыча серого волка находятся в пути», «Верхом на коне добы коня», «На коне пробужАался от сна», очевидно, появились уже после похода Чингиз кагана. Кочевники-казахи стали возвращаться на свои исконные земли», то есть представители всех тех тюркских племен, которые в послеАующем вошли в казахский союз, они в своей исторической памяти сохранили представление о славной эпохе Чингиз кагана, когда он совершал военные походы как собиратель тюркских земель. «Казахи, расположившись у подножия Алатау, - писац Абай, переняли у соседей землелелие и торговлю, скромно называя себя «серыми, темными». Вероятно, кыргызов стац называть кыргызами один из уйгурских ханов. Впереди их конницы обычно ставились так называемые кыргызы - «истребители», «палачи» (от слова «кыру»), подававшие команды: «Убей! Уничтожь! Изведи!» Так появицось слово «кыргызы» (Кунанбаев, 2018).

Такая интерпретация смысла соционима или этнонима «кыргыз», смотря в каком значении его понимать, в трудах Абая, она довольно неожиданно, но, вместе с тем, это определение в некотором смысле претендует на истину, исходя из этимологических значений словообразования и его семантики. При этом следует подчеркнуть, что казахский народ в Аореволюционной России называли не иначе как «киргиз-кайсаки», «киргиз-казаки», и это имя этноса стойко держалось до начала XX века. Конечно, это связано с тем, что во времена казахского Есим хана, он считался одновременно ханом казахов и кыргызов, и его ополчение Аружно ходила на войну с калмыками. В составе казахского народа, помимо кыргызов, которое были полонены ханом Абылаем, были также две категории кыргызов, одни из числа аманатов - «ак уйлі», а Аругие, собственно, те, которые к Алатауским кыргызам не имеют отношения, 
но находились в номенклатуре казахских родоплеменных групп изначально, в качестве первоначацьного составного элемента.

Как писали в своих исследованиях КАяшторный С.Г. и Султанов Т.И.: «по сообщению Махмуда ибн ВаАи, автора многотомной всеобщей истории «Бахр ац-асрар», в составе войска Бату, в частности, были ополчения племен аргун, огуз, найман, буйрак, ойрат, карлук, кушчи, усун, минг, конграт, кереит, бар $а с$. Источники, откуда Махмуд ибн Вали черпал свои сведения о племенном составе войска Бату, нам неизвестны. После завершения военной кампании 1236-1242 гг. большая часть центральноазиатских племен вместе со своими вожАями возвратицась к себе на историческую родину. Но какое-то количество из этих родов и племен было распределено после похода межАу Ажучидами в качестве эля; они стали таким образом «Аештскими». Так, по словам Абу- -Гази и автора «Зублат ал-асар» (XVI в.), Бату после возвращения из похода в Восточную Европу (1242 г.) отАал под власть своего брата, Шибана, народ, состоявший из 15 тысяч семейств, выделив ему из «Аревних родов» (байри элинден) четыре главных племени: кушчи, найман, карлук, буйрак. Аругому своему брату, Тукай-Тимуру, Бату вылелим «из каучинов» (т.е. из привилегированной части войска) минг, тархан, ушун, ойрат» (КАяшторный, Султанов, 2009).

История УАуг УАуса изцожена в материалах, существующих и широко известных исторических источников и на основе заслуженных и популярных, серьёзных научных исследований. Концепции «татаро-монгольское иго» затмила то, что степняки были веротерпимы, и нет свидетельств, что они разрушали церкви, монастыри, наоборот золотоордынские ханы постоянно оказывали им протекцию и защиту, они провозгласили политику невмешательства в лела церкви, объявили запрет на их разграбление и освобождение от податей, и т.А. Заметным стало благотворное влияние на общественно-культурную жизнь народов, например, увеличение лексического строя русского языка, привнесшие такие понятия, как кафтан, колчан, барабан, богатырь, орда, сундук и так далее. Более того, военно-политические традиции

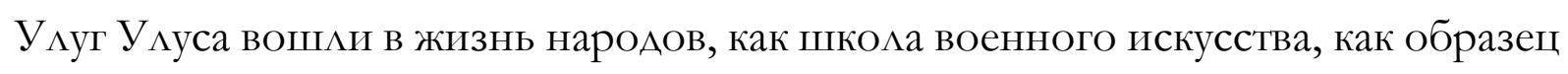
Аля формирования централизованного государства, а дипломатические и посольские отношения были сформированы под влиянием ордынцев в форме неприкосновенности Аипломатических миссий поА страхом жестокого возмезАия. Все это говорит о «благом деянии, добром деле». Ведь население Ао золотоордынской Руси испытывало не меньше притеснений от собственных князей, нежели от правления властителей Золотой Орды. Такие социальные 
категории населения в Аревней Руси, согласно «Русской Правды»как челядь, холопы, смерды, изгой, и т.А. существовали и раньше, и они не появились после прихода татаро-монголов. Но с приходом степняков в общественную жизнь вошли Аругие социальные модели.

История о посольских и Аипломатических связях УАуг УАуса с мамлюкскими султанами Египта, о приёме послов францисканских миссий также важна. «Послам категорически было запрещено брать с собой оружие, Аля очищения их проводили межАу Авумя кострами. Этот обряА, кстати взят из Аревних тюркских традиции, - считается, что огонь очищает Аушу и внутренний мир, снимает порчу и тяжёлое бремя». Это тюркская традиция очищения огнем хорошо описана в трудах востоковеда Ч.Ч. Валиханова (Валиханов, 1904). В У ууг УАусе происходили приемы послов, общепринятые протоколы приема и их особенности у золотоордынских ханов, как например, посол Аолжен был встать на одно колено, или на обе колени. Известна история расправы хорезмшаха с послами Чингиз-хана, ставшее началом и предпосылкой военных походов Чингиз-хана. И ещё раз такая история с убийством послов получилось уже при Хулагу, известном по казахским эпическим преданиям, как А^еуке, который убиц послов от Берке хана, и нарушил, тем самым, Аипломатические правила. Можно было бы включить какие-то переписки межАу Тохтамысом и Эмиром Тимуром, и Аругие документы (Миргалеев, 2003).

История УАуг УАуса позАнего времени, до времени его окончательного распада, включая рассмотрение экономики, хозяйства, быта и социума, правителей этого периода Мамай и Узбек хан. Урусхан (Акнияз) - предок казахских ханов, Хан Токтамыс и эмир ЕАиге, Тамерлан и разрушение Укуг УАуса (Золотой Орды). Описание истории целой страны - государства УАуг Укус, его исторических персон и выдающихся мичностей, военной организации, традиции политического управцения, путей и сообщений, городов и торгов и, культурной жизни, мотивы повеАения Аюдей и населения в целом. Вопросы мокализации ханских ставок Ак Орды и Кок Орды рассматривались в различных публикациях, и приобрёл несколько Аискуссионный характер (Сабитов и Кушкумбаев, 2013).

Исторический сюжет известных по историческим источникам фактов, связанных с развитием истории УАуг У уса, но со вкцючением каких-то новых элементов, новый анализ смыслов, значений и подтекстов специфических терминов и понятий кочевого мира, а также новая оценка роли, места и значения государства УАуг УАус, его экономическое и военно-политическое 
воздействие на окружающий мир, которое раньше было трудно свободно анализировать, высказывать, сюжеты военно-политической и государственной, имперской деятельности наиболее видных милеров УАуг У муса могут быть также рассмотрены в контексте исторической памяти.

\section{Аискуссия}

В Аанной статье предпринята попытка переосмысления истории УАуг Укуса в контексте тюркских источников шежире - исторической памяти казахского народа, которая отложилась в историческом фольклоре, традиции народных пословиц и поговорок, отражающие исторические события времён Чингиз кагана и его потомков, зафиксированные в работах Абая Кунанбаева, Машхур-Жусуп Копеева, Отыншы А^ьжанова, Шакарима Кудайбердиева, Мухамеджана Тынышбаева, Халела Аосмухамедова, и других авторов.

Необходимость такого подхода была продиктована тем, что Алительное время казахские исторические источники игнорировались, не признавались, предавались забвению, а мичности, которые являлись продолжателями и хранителями этой траАиции, сторонниками такой точки зрения подвергались гонениям, политическим репрессиям, преследованиям. МежАу тем, советская научная историография строила собственную интерпретацию и понимание золотоордынской истории, которая была усеченной, однобокой, порицаемой и в обвинительных тонах, в некоторых позициях подложной, и даже ставилась под запрет или табу Аля исследователей.

Как бы то ни было, в настоящее время, историческая наука должна принять во внимание весь массив исторической информации, подвергнуть их критическому анализу, и с позиции научной объективности дать оценку их возможностей в реконструкции исторической реацьности изучаемой эпохи и событий. В этом отношении Аля нас важно проследить культурноисторические связи казахов с Аругими тюркоязычными и тюркскими по своему происхождению братскими народами, а также их взаимодействий с представителями других народов и конфессий, населявших Евразию.

Хотелось бы, чтобы будущие исследователи данной темы подробнее остановиться на следующих вопросах:

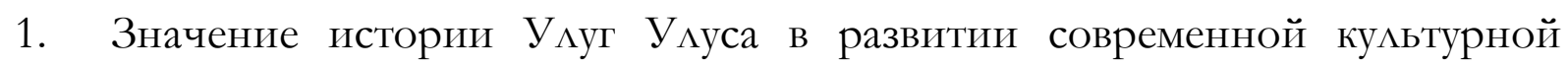
интеграции тюркского мира.

2. Воссоздание истории Великой степи на основе исторической памяти тюркского мира. 
3. Подход к Аанному вопросу на основе ранее мало изученных источников и с позиций разАичных научных Аисциплин.

Исследование темы истории УАуг УАуса в таких направлениях дало бы более продуктивные результаты в условиях современной глобализации и процессов современной интеграции. Это поспособствует отходу от тех конструкций Аеления, которые были некогда навязаны колониальной политикой Российской империи, преследовавшей цель размежевания единого тюркского сообщества.

\section{Заключение}

Таким образом, в изучении истории УАуг У ууса кроме рассмотрения частных вопросов, важен также общий взгляА на исторический процесс, связанный с этим государством. Кроме того, необходимо использовать не только внешние историографии и внешние источники, но и историографии внутренние, и внутренние источники, которые формируют собственное видение своей истории у тюркских народов, основанной на исторической колмективной памяти самого субъекта изучаемой истории.

\section{Список источников информации:}

Абзалов, А.Ф. и Ар. (2016). Золотая Орда в мировой истории. Коллективная монография. Казань: Институт истории им. Ш. Марджани АН РТ.

Акишев, А.К. (2004) «Сиюйцзи» - «Записки о Западном крае» даоского Учителя Чань Чуня. Журнал «Тамъьр, 12, 52-71.

Алпысбес, М.А. (2021). Рецензия на книгу: «Аяган Б.Г. История Уиуг У ууса Золотой Орды: курс мекций. Золотоординское наследие: сборник статей, посвященный 700-летито со дня рождения средневекового татарского поэта Сейфа Сараи, 4, 321-330. Казань: Институт истории им. Ш. Марджани АН РТ.

Алпысбес, М.А. (2004). Чингиз-хан в контексте этнической истории тюркомонгольских народов (по материалам Рашил аА-Аина и шежире). Историкокультурные взаимосвязи Ирана и Аашт-и Кипчака в XIII-XVIII вв.: материальг международного круглого стола, 215-232. Алматы: Аайк-Пресс.

Анареев, И.Г. (1998). Описание Средней Ордъг киргиз-касаков. Алматы: Ғылым.

Аяган, Б.Г. (2020). История Улуг Улуса - Золотой Орды. Курс лекций. Алматы: ТОО «итера - М».

Аяган, Б.Г. (2014). Рассветь и сумерки казахской степи. Алматы: ТОО «Аитера-М». 
Валиханов, Ч.Ч. (1904). Сочинения Чокан Чингиовича Валиханова. СанктПетербург: Типография главного управления улемов.

Веселовский, Н.И. (1922). Хан из темников Золотой Орды Ногай и его время. Записки РАН по отделению исторических наук и филологии, 13, б. ПетрограА.

Кадырбаев, А.Ш. (1992). Казахстан в эпоху Чингиз-хана и его преемников. XII-XIV 6в. Алма-Ата: Гылым.

Кадырбаев, А.Ш. (1990). Тюрки и иранщьг в Китае и Центральной Азии ХІІІ-XIV вв. Алма-Ата: Гылым (Наука).

Кадырбаев, А.Ш., Сыздыкова, Ж.С. (2017). К вопросу об исторических преемниках Золотой Орды. ХІІІ Фаизхановские чтения. Наследие Золотой Орды в государственности и культурных традичиях народов Евразии: материальг международной научно-практической конферениии, 54-65. Москва: ООО «Издательский дом “Медина"».

КАяшторный, С.Г., Султанов, Т.И. (2009) Государства и народы Евразийских степей: от Аревности к Новому времени. Санкт-Петербург: Петербургское востоковедение.

Көпеев, М.Ж. (1993). Атасының аты білінбей өзі аты шыққан ерлер. Ақ-Орда. № 2.

Көпейұлы, М.Ж. (1993) Қазақ шежіресі. Аайъънд. С. Аәуімұль. Алматы.

Кудайбердиев Ш. (1990) Родословная тюрков, казахов, киргизов и династии ханов.

Перевод Б. Каирбекова. Алма-Ата: Жазушы: СП «Аастан».

Кумеков, Б., Султанов, Т. (1974). ВклаА русских и советских ученыхвостоковедов в изучение средневековой истории Казахстана. Известия АН КазССР. Серия обшественных наук, 2, 14-23.

Кунанбаев, А. (2018) Несколько слов о корнях происхождения казахов (Перевод с казахского М. Султанбекова). В кн.: Кунанбаев, А. Сочинения. Том. 2. Астана: Фолиант. С. 242-247.

Маргулан, А.Х. (2007). Сочинения. Казахский народнъий эпос. Т. 3. Алматы: «Алатау». Миргалеев, И.М. (2003). Политическал история Золотой Ордъг периода правления Токтамыш-хана. Казань: Алма-Аит.

Сабитов, Ж.М. (2015). «Золотая Орда - «падчерица» казахстанской историографии». Молодой учёныци, 24 (104), 842-851.

Сабитов, Ж.М., Кушкумбаев, А.К. (2013). УАусная система Золотой Орды в XIII-XIV веках: к вопросу мокализации Ак-Орды и Кок-Орды. Золотоординское обозрение, 2, 60-72.

Сейфулмин, С. (2007). Шызъцмаларыл. 7-ші том. Алматы: «Қазыгурт» баспасы. Султанов, Т.И. (2006). Чингиз-хан и чингизидъ. Судьба и власть. Москва: АСТ. 
Утемиш хаджи. Чингиз-наме (1992). Факсимиле, перевод, транскрипция, примечание, исследование В.П. ЮАина. Комментарии и указатели М.Х. Абусеитовой. Алматы.

Утемиш хаджи. Кара таварих. Факсимиле (2019). Подготовка к изданию И.М. Миргалеев, Э.Г. Сайфетдинова. Казань. 